\title{
BUSINESS JUDGEMENT RULE SEBAGAI PERLINDUNGAN HUKUM BAGI DIREKSI PERSEROAN DALAM MELAKUKAN TRANSAKSI BISNIS
}

\author{
Oleh : \\ Muhammad Gary Gagarin Akbar \\ Universitas Buana Perjuangan Karawang \\ Email : Gagaringary@gmail.com
}

\begin{abstract}
ABSTRAK
Direksi mempunyai peran yang sangat vital bagi perseroan. Direksi ibarat nyawa bagi perseroan, tidak mungkin suatu perseroan tanpa adanya direksi. Direksi bertugas sebagai perwakilan perseroan dalam menjalankan perseroan. Dalam prakteknya, direksi sering kali dirugikan akibat keputusan bisnis yang diambilnya. Hal ini diakibatkan oleh belum adanya harmonisasi undang-undang mengenai definisi keuangan negara sehingga memungkinkan direksi dikenakan tindak pidana korupsi jika direksi dalam mengambil keputusan bisnis menimbulkan kerugian bagi perseroan. Jika direksi dalam mengambil suatu keputusan tidak mendapatkan perlindungan hukum maka direksi menjadi takut untuk mengadakan transaksi bisnis. Karena itu dalam hal ini sangat dibutuhkan doktrin Business Judgement Rule sebagai perlindungan hukum bagi direksi dalam melakukan transaksi bisnis agar mereka bisa menjalankan tugasnya dengan maksimal. Selain itu, jika direksi membuat keputusan bisnis yang menimbulkan kerugian untuk perseroan dikarenakan ultra vires atau melampaui kewenangan yang telah ditentukan dalam anggaran dasar atau peraturan perundang-undangan yang berlaku, maka direksi tersebut tidak bisa dilindungi oleh doktrin Business Judgement Rule. Dalam hal direksi melakukan tindakan ultra vires, maka direksi tersebut dapat dikenakan Pasal 97 ayat (3) UUPT, pasal ini menyatakan bahwa setiap anggota direksi bertanggung jawab penuh sampai pada harta pribadi apabila direksi tersebut melakukan kesalahan atau kelalaian yang mengakibatkan perseroan mengalami kerugian, kemudian direksi BUMN juga dapat dikenakan Pasal 1365 mengenai perbuatan melawan hukum yang mengakibatkan kerugian pada orang lain, maka harus membayar ganti rugi kepada pihak yang dirugikan.
\end{abstract}

Kata Kunci: Direksi, BUMN, Business Judgement Rule 


\begin{abstract}
Directors have a very important role for company. Directors like soul of the company, impossible a company without directors. Directors served as representative of the company in running the company. In practice, directors are often adversely affected business decision taken. This is caused by the absence of harmonization of legislation on the definition of state finances so as to enable the directors subject to corruption if the directors in making business decisions result in losses for the company. If the directors in taking a decision not to get legal protection, the directors be afraid to conduct business transactions. Therefore in this case is necessary doctrine of Business Judgment Rule as legal protection for directors in the transaction of business so that they can carry out their duties to the fullest. In addition, if directors make business decisions causing losses to the company due to the ultra vires or beyond the authority specified in the statutes or regulations applicable law, the directors can not be protected by the doctrine of the Business Judgment Rule. In the event that the directors act ultra vires, the directors may be subject to Article 97 paragraph (3) of legislation limited liability company, this article states that each member of the board of directors fully responsible to the personal property if the directors of wrongdoing or negligence which resulted in the company at a disadvantage, then the board of directors SOE also be subject to Article 1365 of the unlawful act that caused financial losses to others, it must pay compensation to the injured party.
\end{abstract}

Keywords : Directors, State Owned Enterprises, Business Judgement Rule (BJR)

\title{
A. Pendahuluan
}

\section{Latar Belakang}

Keberadaan direksi dalam perseroan merupakan suatu keharusan, atau dengan kata lain perseroan wajib memiliki direksi, karena perseroan sebagai artifical person tidak dapat berbuat apa-apa tanpa adanya bantuan dari anggota direksi sebagai natural person. ${ }^{1}$ Direksi dalam Perseroan Terbatas ibarat nyawa bagi perseroan. Tidak mungkin suatu perseroan tanpa adanya direksi. Sebaliknya tidak mungkin ada direksi tanpa adanya perseroan. Oleh karena itu keberadaan direksi bagi perseroan sangat penting. Sekalipun Perseroan Terbatas sebagai badan hukum yang mempunyai kekayaan terpisah dari direksi, tetapi hal itu hanya berdasarkan fiksi hukum, bahwa perseroan dianggap seakan-akan sebagai subyek hukum, sama seperti manusia. ${ }^{2}$

${ }^{1}$ I.G. Rai Wijaya, Hukum Perseroan Terbatas, (Jakarta: Kesain Blanc, 2002), hlm. 1.

${ }^{2}$ Try Widiyono, Direksi Perseroan Terbatas, Keberadaan, Tugas, Wewenang, dan Tanggung Jawab, (Jakarta: Ghalia Indonesia, 2004), hlm. 7. 
Wewenang atau kekuasaan yang dimiliki oleh seorang direksi suatu perseroan di dasarkan atas posisinya sebagai organ perseroan, artinya sebagai alat perlengkapan perseroan (badan hukum). Dalam posisinya sebagai organ perseroan dalam bertindak dibatasi atas wewenang yang diberikan kepadanya selaku pihak mewakili perseroan (badan hukum). Seseorang yang menduduki posisi sebagai direksi kemungkinan bertanggung jawab secara pribadi atas tindakan atau perbuatan yang dilakukan untuk perseroan yang diwakilinya. Hal ini bisa terjadi apabila ia melakukan suatu tindakan atas perbuatan yang tidak menjadi wewenangnya atau melampaui batas wewenangnya. ${ }^{3}$

BUMN merupakan istilah lain dari Perusahaan Negara (State Owned Enterprise/SOEs). Istilah tersebut baru dikenal sejak diterbitkannya Peraturan Pemerintah Nomor 3 Tahun 1983. Perusahaan Negara atau yang sekarang dikenal dengan BUMN merupakan badan hukum korporasi dengan modal yang dimiliki, baik sebagian ataupun seluruhnya oleh Negara melalui penyertaan secara langsung yang berasal dari kekayaan Negara yang dipisahkan. ${ }^{4}$

Seperti yang sudah dijelaskan diatas, bahwa BUMN mendapatkan modal dari kekayaan negara yang sudah dipisahkan, artinya ketika negara memutuskan untuk memberi modal kepada Perseroan maka modal tersebut lepas dari negara, dan disini negara berkedudukan sebagai pemegang saham dalam Perseroan. Dalam prakteknya, seringkali dicampuradukan antara uang perseroan dengan uang negara. Berkaitan dengan itu, dalam kasus yang terjadi pada Direktur Utama PT Merpati Nusantara Airlines, Hotasi Nababan dikenakan Tindak Pidana Korupsi akibat keputusan bisnis yang ambil olehnya ternyata mengakibatkan kerugian bagi perseroan. Inilah yang menjadi persoalan dimana akibat tidak adanya harmonisasi antara definisi mengenai keuangan yang terdapat pada UU BUMN, UU Keuangan Negara, UU Perbendaharaan Negara, dan UU Tindak Pidana Korupsi.

Berdasarkan uraian tersebut diatas, maka diperlukan suatu perlindungan hukum bagi direksi perseroan agar dalam mengambil sebuah keputusan bisnis tidak dibayang-bayangi oleh ancaman pidana korupsi apabila nantinya ternyata keputusan bisnis tersebut berakibat kerugian pada perseroan. Dalam hukum perusahaan dikenal adanya doktrin Business Judgement Rule (BJR) yang memberikan suatu imunitas bagi direksi apabila perseroan mengalami kerugian akibat transaksi bisnis yang diambil. Dalam tulisan ini, penulis juga membahas tentang Putusan Nomor 1144/K/Pid/2006 untuk sebagai perbandingan

\footnotetext{
11.00

${ }^{3}$ http://fh.unsoed.ac.id/sites/default/files/VOL8J2008\%20TRUSTO\%20SUBEKTI.pdf 30 Mei 2014

${ }^{4}$ Pasal 1 angka 1 UU BUMN.
} 
penggunaan Business Judgement Rule (BJR) dan mengkaji mengenai pertanggungjawaban direksi apabila perseroan mengalami kerugian akibat keputusan bisnis yang diambil.

\section{Kajian Teori}

Ultra vires berasal dari bahasa Latin yang berarti diluar atau melebihi kekuasaan (outside the power), yakni diluar kekuasaan yang dijinkan oleh hukum terhadap badan hukum. Terminologi ultra vires dipakai khususnya terhadap tindakan perseroan yang melebihi kekuasaannya sebagaimana diberikan oleh anggaran dasarnya atau peraturan yang melandasi pembentukan perseroan tersebut. ${ }^{5}$ Pada umumnya suatu perbuatan dikatakan ultra vires bila dilakukan tanpa wewenang (authority) untuk melakukan perbuatan tersebut. Bagi perseroan perbuatan tersebut adalah ultra vires bila lakukan diluar/melampaui wewenang direksi atau perseroan sebagaimana tercantum dalam anggaran dasar dan hukum perusahaan. Suatu kontrak yang dibuat oleh perseroan dan melampaui batas wewenangnya adalah tidak sah (unlawful). Doktrin ultra vires berdampak pada perikatan antara perseroan dan pihak ketiga, dimana transaksi yang dilakukan bersifat ultra vires adalah tidak sah dan tidak dapat disahkan kemudian oleh suatu Rapat Umum Pemegang Saham (RUPS). Dengan demikian, perseroan dapat menolak melaksanakan kewajiban berdasarkan kontrak. ${ }^{6}$

Berdasarkan doktrin hukum Perseroan Terbatas Direksi dalam menjalankan tugasnya mempunyai kewajiban melaksanakan pengurusan dengan penuh tanggung jawab antara lain:

\section{Fiduciary Duty}

Setiap anggota direksi "wajib dipercaya" dalam melaksanakan tanggung jawab pengurusan perseroan. Berarti setiap anggota direksi selamanya dapat dipercaya (must always bonafide) serta selamanya harus jujur (must always honested). Mengenai makna itikad baik dan wajib dipercaya serta selamanya wajib jujur dalam memikul tanggung jawab atas pelaksanaan pengurusan perseroan, ada ungkapan yang berbunyi a director is permitted to be very stupid so long as he is honest (dibenarkan seorang direktur yang sangat bodoh asal dia jujur). Hal ini bukan berarti disetujui mengangkat seorang direksi yang bodoh. Yang diinginkan oleh ungkapan itu adalah mengangkat anggota direksi yang cakap sekaligus jujur, daripada pintar tetapi tidak jujur dan tidak dapat dipercaya. ${ }^{7}$

2. Duty of Care

\footnotetext{
${ }^{5}$ Ridwan Khairandy, Perseroan Terbatas, Doktrin, Peraturan Perundang-undangan, dan Yurisprudensi, Cet.2 (Yogyakarta: Kreasi Total Media, 2009), hlm. 227.

${ }^{6}$ Chatamarrasjid Ais, Penerobosan Cadar Perseroan dan Soal-soal Aktual Hukum Perseroan, Cet.1 (Jakarta: Citra Aditya Bakti, 2004), hlm. 41.

${ }^{7}$ http://repository.usu.ac.id/bitstream/123456789/37040/4/Chapter\%20II.pdf29 Mei 201420.30
} 
Direktur dalam menjalankan perusahaan berdasarkan kewenangan yang ada harus selalu waspada dan bertindak dengan perhitungan yang cermat. Dalam kebijakan yang dibuatnya direktur harus selalu bertindak dengan hati-hati dan mempertimbangkan keadaan, kondisi, dan biaya pengelolaan yang besar. ${ }^{8}$ Dalam mengurus perseroan, anggota direksi tidak boleh "sembrono" (caressly) dan "lalai" (negligence). Apabila dia sembrono dan lalai melaksanakan pengurusan, menurut hukum dia telah melanggar kewajiban berhati-hati (duty care) atau bertentangan dengan "prudential duty". Patokan kehati-hatian (duty of the due care) yang diterapkan secara umum dalam praktik, adalah standar kehati-hatian yang lazim dilakukan orang biasa dalam posisi dan kondisi yang sama. Apabila patokan kehati-hatian ini diabaikan oleh anggota direksi dalam menjalankan pengurusan perseroan, dia dianggap bersalah melanggar kewajilban mesti melakukan pengurusan dengan penuh tanggung jawab. Tidak ada maaf bagi seseorang yang menduduki jabatan anggota direksi dengan gaji dan tunjangan yang cukup besar, tetapi tidak hati-hati melaksanakan pengurusan perseroan. ${ }^{9}$

\section{Duties of Loyalty}

Sikap setia yang harus ditunjukkan oleh direksi dalam perusahaan adalah sikap yang didasarkan pada pertimbangan rasional dan profesional. Dalam arti ini, direksi harus mampu bersikap tegas sesuai dengan visi dan misi serta anggaran dasar perseroan terbatas. Maksud dari kesetiaan adalah direksi harus selalu berpihak pada kepentingan perusahaan yang dipimpinnya. Direksi yang diberikan kepercayaan oleh pemegang saham harus bertindak untuk kepentingan pemegang saham dan stakeholders, bertindak untuk kepentingan dan tujuan perseroan, serta bertindak dengan mengutamakan kepentingan perseroan di atas kepentingan pribadi. ${ }^{10}$ Terkait dengan duty of loyalty, direksi juga dilarang untuk melakukan hal-hal seperti bersaing dengan perusahaan tersebut, merebut kesempatan yang ada dalam perusahaan, merealisasikan keuntungan pribadi yang berasal dari informasi material yang ada, menggunakan aset perusahaan demi kepentingan pribadinya, dan ikut serta dalam pembuatan perjanjian yang memunculkan adanya benturan kepentingan. ${ }^{11}$

\section{Duties of Skill}

Kemampuan atau keahlian mengurus perseroan merupakan persyaratan yang harus dimiliki oleh direksi dan komisaris. Sebagai pucuk pimpinan suatu perseroan, kualifikasi

${ }^{8}$ Ridwan Khairandy, Perseroan..., op.cit, hlm. 210.

${ }^{9}$ M. Yahya Harahap, Hukum Perseroan Terbatas, Cet.1, (Jakarta: Sinar Grafika, 2011), hlm. 379

${ }^{10}$ Ridwan Khairandy, Pokok-Pokok..., op.cit, hlm. 113

${ }^{11}$ Ridwan Khairandy, Perseroan..., op.cit, hlm. 212. 
profesional ini menjadi persyaratan yang tidak dapat ditawar. ${ }^{12}$ Selain itu direksi juga harus memiliki kewajiban yang disebut duty to be dilligent and skill yaitu wajib tekun dan ulet. Pada umumnya aspek tekun dan ulet, selalu dikaitkan dengan keahlian (skill). Dengan demikian, anggota direksi dalam melaksanakan pengurusan perseroan, wajib mempertunjukan kecakapan (duty to display skill). Patokannya, kecakapan atau keahlian yang wajib sesuai dengan jabatan direksi yang dipangkunya (reasonable skill for the post). Kecakapan dan keahlian yang wajib ditunjukkannya, harus berdasar ilmu pengetahuan dan pengalaman yang dimilikinya (according to his knowledge and experience). ${ }^{13}$

\section{Duties to Act Lawfully}

Direksi yang diberi kepercayaan oleh pemegang saham berkewajiban untuk memimpin perseroan sesuai dengan hukum atau peraturan yang berlaku. Apabila direksi mengetahui perbuatan yang akan dilakukannya bertentangan dengan hukum atau peraturan yang berlaku, maka pengurus perseroan tersebut sudah seharusnya tidak melakukannya. Direksi dalam menjalankan tugas perseroan harus sesuai dengan ketentuan dari UUPT dan anggaran dasar perseroan, tugas tersebut harus dilaksanakan dengan penuh kehatihatian, itikad baik, konsekuen, dan konsisten. ${ }^{14}$

Salah satu hal yang terkait dengan perihal kewenangan direksi adalah soal prinsip Business Judgement Rule. ${ }^{15}$ Business Judgement Rule adalah salah satu dari beberapa doktrin dalam hukum perusahaan yang harus dijalankan oleh direksi perseroan terbatas guna memenuhi fiduciary duty. Doktrin ini ada awalnya digunakan dalam hukum perusahaan negara Amerika Serikat. ${ }^{16}$

Business Judgement Rule menurut Ridwan Khairandy, merupakan doktrin yang mengajarkan bahwa direksi perseroan tidak bertanggung jawab atas kerugian yang timbul dari suatu tindakan pengambilan putusan, apabila tindakan tersebut didasarkan pada iktikad baik dan hati-hati. Direksi mendapat perlindungan hukum tanpa perlu memperoleh

\footnotetext{
${ }^{12}$ Ibid

${ }^{13}$ M. Yahya Harahap, op.cit, hlm. 381.

${ }^{14}$ Ridwan Khairandy, Perseroan..., op.cit, hlm. 212.

${ }^{15}$ Binoto Nadapdap, Hukum Perseroan Terbatas, Cet.1 (Jakarta: Permata Aksara, 2013), hlm. 97.

${ }^{16}$ Prasetio, Dilema BUMN, Benturan Penerapan Business Judgement Rule (BJR) dalam keputusan
} Bisnis Direksi BUMN, Cet.1 (Jakarta: Rayyana komunikasindo: 2014), hlm. 143. 
pembenaran dari pemegang saham atau pegadilan atas keputusan yang diambilnya dalam konteks pengelolaan perusahaan. ${ }^{17}$

Pengertian doktrin itu sendiri adalah pendapat atau teori para ahli hukum. C.S.T. Kansil dan Christine Kansil mengatakan bahwa kedudukan doktrin sendiri dalam praktiknya sangatlah penting dalam mempengaruhi pengambilan keputusan hukum oleh hakim. Dalam mengambil keputusan, hakim sering kali mengutip pendapat atau teori dari seorang atau beberapa orang ahli hukum mengenai kasus yang dihadapinya, apalagi jika ahli hukum tersebut juga menyatakan mengenai bagaimana penyelesaian suatu kasus sampai dengan selesai. Jadi, dengan kata lain, kedudukan doktrin merupakan sebuah sumber hukum yang sangat berpengaruh bagi keputusan-keputusan hakim selain undang-undang. Pendapat serupa juga disampaikan oleh Sudikno Mertokusumo bahwa doktrin sebagai pernyataan atau pendapat seseorang atau beberapa ahli hukum merupakan salah satu sumber hukum. Adapun sumber hukum formal yang berlaku dalam hukum positif Indonesia adalah: ${ }^{18}$

a) Undang-undang (statute);

b) Kebiasaan (custom);

c) Keputusan-keputusan hakim (jurisprudentie);

d) Traktat (treaty); dan

e) Pendapat ahli hukum (dokrin).

Doktrin (doctrine) sangat erat kaitannya dengan keputusan-keputusan hakim (yurisprudensi). Hal ini karena, dalam menjatuhkan putusan, seorang hakim akan mengambil pertimbangan hukumnya dengan mengacu kepada pendapat para ahli hukum (doktrin). Karenanya, terlepas dari sistem hukum yang dianut oleh suatu negara, maka doktrin tetap merupakan sumber hukum. Tidak mengherankan apabila doktrin Business Judgement Rule dalam hukum perusahaan tidak hanya berkembang di negara-negara dengan sistem hukum Common Law saja, tetapi juga pada penganut sistem hukum lainnya. ${ }^{19}$

Menurut Nindyo Pramono, Business Judgement Rule dipergunakan untuk melindungi direksi dan jajarannya dari setiap kebijakan atau keputusan bisnis atau transaksi bisnis yang dilakukan untuk kepentingan perseroan sesuai dengan maksud dan tujuan perseroan, dengan cacatan bahwa selama kebijakan atau keputusan bisnis atau transaksi bisnis tersebut dilaksanakan sejalan dengan wewenangnya dan dengan mengedapankan prinsip kehati-hatian

\footnotetext{
${ }^{17}$ Ridwan Khairandy, Perseroan..., op.cit, hlm. 234.

${ }^{18}$ Prasetio, op.cit, hlm. 144.

${ }^{19}$ Ibid, hlm. 146.
} 
(prudent). Itikad baik (good faith), dan penuh tanggung jawab (accountable/responsible). ${ }^{20}$ Jadi, Business Judgement Rule adalah perlindungan hukum bagi direktur dan jajarannya dari pertanggungjawaban atas setiap kebijakan atau keputusan bisnis atau transaksi yang mengakibatkan kerugian bagi perusahaan, selama kebijakan atau keputusan bisnis atau transaksi bisnis tersebut dilakukan dengan itikad baik, penuh kehati-hatian, kejujuran, sejalan dengan tanggung jawab dan wewenangnya. ${ }^{21}$

\section{B. Metode Penelitian}

Penulis dalam tulisan ini menggunakan metode penelitian yuridis-normatif (doctrinal legal research atau pure legal research) yaitu penelitian hukum yang bersandar pada bahan pustaka atau data sekunder yaitu dengan pendekatan perundang-undangan. Obyek dalam tulisan ini yaitu mengenai Business Judgement Rule sebagai perlindungan hukum bagi direksi dalam melakukan transaksi bisnis

\section{Hasil dan Pembahasan}

\section{Business Judgement Rule Sebagai Perlindungan Hukum Bagi Direksi Perseroan dalam Melakukan Transaksi Binis}

Salah satu kasus yang berkaitan dengan Business Judgement Rule yaitu kasus PT. Merpati Nusantara Airlines (MNA). Dalam kasus ini telah terjadi kriminalisasi terhadap Direktur Utama, Hotasi Nababan. Kasus ini bermula dari perbuatan Hotasi Nababan untuk mendatangkan 2 (dua) pesawat Boeing 737-400 dan Boeing 737-500 pada Desember 2006 dan membayar "security deposit" (uang deposit) sebesar US\$1 juta sebagai jaminan pembelian pesawat kepada pihak lessor, Thirdstone Aircraft Leasing Group (TALG), dianggap melanggar hukum. Kegagalan TALG menyerahkan kedua pesawat serta menolak mengembalikan deposit tersebut dianggap sebagai bukti telah terjadinya kerugian negara. Padahal, dana untuk pengadaan pesawat tersebut telah disetujui dan ditandatangani oleh seluruh direksi. Alasan penyewaan dua unit pesawat tersebut juga didasarkan pada perhitungan bisnis. Namun, jaksa penuntut umum (JPU) dalam tuntutannya mengatakan perbuatan Hotasi Nababan adalah melanggar hukum yang menimbulkan kerugian negara.

\footnotetext{
${ }^{20}$ Nindyo Pramono, "Beauty Contest sebagai Business Judgement Rule versus Persaingan Usaha Tidak Sehat”, http://www.hukumonline.com 10 September 201420.00 WIB.

${ }^{21}$ Prasetio, op.cit, hlm. 151.
} 
Jaksa Penuntut Umum (JPU) kemudian menuntut Hotasi Nababan dengan empat tahun penjara ditambah denda Rp.500 juta subsider enam bulan kurungan berdasarkan dakwaan subsider yaitu Pasal 3 juncto Pasal 18 UU Nomor 31 Tahun 1999 sebagaimana telah diubah dengan UU Nomor 20 Tahun 2001 tentang Pemberantasan Tindak Pidana Korupsi juncto Pasal 55 ayat (1) ke-1 KUHP tentang perbuatan merugikan keuangan negara. Namun pada akhirnya majelis hakim Pengadilan Tindak Pidana Korupsi (Tipikor) Jakarta menyatakan terdakwa Hotasi Nababan tidak terbukti secara sah dan menyakinkan bersalah melakukan tindak pidana korupsi sehingga membebaskan Hotasi Nababan dari segala dakwaan.

Perbuatan yang dilakukan oleh Hotasi Nababan yang membayar sewa pesawat Boeing 737-400 dan 737-500 dan membayar security deposit sudah dilakukan dengan hati-hati, dengan itikad baik, sesuai kondisi perusahaan serta dengan informasi yang dinilai cukup sehingga tuntutan yang diajukan JPU tersebut tidak tepat. Apalagi Pengadilan di Amerika Serikat telah memutus bahwa TALG telah melakukan wanprestasi terhadap PT. Merpati Nusantara Airlines. TALG telah dihukum agar mengembalkan uang jaminan yang telah dibayar Merpati sebesar US\$ 1 juta beserta bunganya.

Kemudian dalam kasus PT. Bank Mandiri Tbk (Persero), direksi tidak bisa menggunakan doktrin Business Judgement Rule, karena direksi dalam mengelola perseroan tidak melakukan prinsip kehati-hatian (due care) dan melanggar peraturan perundangundangan yang berlaku.

- Kasus Direktur Utama PT Bank Mandiri Tbk (Persero)

Dalam kasus direktur PT. Bank Mandiri Tbk (Persero) yaitu ECW Neloe berawal dari Para pemutus kredit tersebut yang dipimpin oleh ECW Neloe menyetui pemberian kredit kepada PT. Cipta Graha Nusantara sejumlah 160 Milyar Rupiah yang tertuang dalam Nota Analisa Kredit Bridging Loan No. CGR.CRM/314/2002 tanggal 23 Oktober 2002 perihal permohonan fasilitas pemberian Bridging Loan yang diajukan Edyson selaku direktur utama PT. Cipta Graha Nusantara sejumlah 160 Milyar Rupiah. ECW Neloe beserta anggotanya yang bertindak sebagai pemutus kredit dalam menyetui pemberian kredit Bridging Loan sebesar 160 Milyar Rupiah tidak memperhatikan Ketentuan Pedoman Pelaksanaan Kredit PT. Bank Mandiri Bab VI buku II tentang informasi dan data dari debitur PT. Cipta Graha Nusantara yang mana salah satu persyaratannya debitur harus menyerahkan daftar jaminan yang menunjukkan jenis barang, jumlah ukuran, lokasi, nilai, status kepemilkan dan copy bukti kepemilikan. Namun pada kenyataannya di dalam nota analisa kredit bridging loan, agunan hanya berupa tagihan dari PT. Tahta Medan kepada PT. Manunggal Wiratama yang 
diketahui akhirnya ternyata PT. Manunggal Wiratama tidak pernah ada. Agunan tersebut diikat dengan fiducia, namun pemutus kredit tetap menyetujui kredit bridging loan padahal agunan Fiducia Eigendom Overdracht (FEO) tidak dibuatkan akta pengikatan.

Setelah pemutus kredit menyetui kredit bridging loan sejumlah 160 Milyar Rupiah,ternyata dana kredit tersebut telah dicairkan kepada PT. Cipta Graha Nusantara padahal dalam prosesnya jelas tidak sesuai dengan ketentuan yang telah ditetapkan oleh perseroan. Pada saat jatuh tempo sesuai jadwal pembayaran debitur PT. Graha Cipta Nusantara seharusnya membayar angsuran pokok Triwulan IV 2003 sampai dengan Triwulan II 2005 sejumlah US\$ 6.300.000, namun kenyataannya PT. Cipta Graha Nusantara hanya membayar angsuran pokok tangal 23 Juni 2005 sebesar US\$ 150.000, sehingga angsuran pokok yang tidak dibayar sejumlah US\$ 6.150.000 atau setara dengan Rp. 58.425.000.000 (kurs Rp.9500,-). Sesuai dengan Nota Analisa Kredit Bridging Loan sejumlah Rp. 160 Milyar adalah dari kredit investasi yang akan diberikan dalam rangka refinancing pembelian aset kredit PT. Tahta Medan dengan jumlah maksimum Rp. 165 Milyar. Dalam Nota Analisa Kredit Investasi jaminan kredit yang telah disetujui pemutus kredit ternyata terdapat permasalahan yaitu jaminan utama adalah tagihan kepada PT. Tahta Medan senilai USD 31,012,961.09 diikat fiducia. Jaminan kredit tersebut secara fiducia berarti Bank Mandiri tidak menguasai secara fisik dan tidak ada kepastian tentang kesanggupan PT. Tahta Medan. Kemudian jaminan tambahan berupa berupa rumah dijelaskan bahwa akan diikat yuridis sempurna namun kenyataanya pengikatan secara notariil, baru dilakukan tahun 2005 dan belum didaftarkan di Badan Pertanahan Nasional untuk diterbitkan Hak Tanggungan.

Dari cara-cara pemutus kredit yang dipimpin oleh ECW Neloe memproses sampai pengeluaran pinjaman, menunjukkan ketidakhati-hatian para pemutus kredit, sesuatu yang secara nyata melanggar asas kehati-hatian dalam perbankan. Ketidakhati-hatian tersebut dengan sengaja dilakukan dengan mengeluarkan suatu kebijakan dengan alasan-alasan yang tidak memadai, karena terbukti tidak ada keadaan obyektif. Para pemutus kredit tersebut yang dipimpin ECW Neloe memproses pinjaman dalam waktu yang begitu cepat yang sematamata menggantungkan pada dokumen dari pemohon tanpa menganalisis keadaan nyata dari pemohon. Berdasarkan hal-hal tersebut di atas perbuatan ECE Neloe sebagai pemutus kredit melanggar Pasal 49 ayat (1) huruf a Undang-Undang Nomor 7 tahun 1992 sebagaimana yang telah diubah dengan Undang-Undang Nomor 10 tahun 1998 tentang Perbankan yang menyatakan bahwa "Anggota Dewan Komisaris, Direksi, atau pegawai bank yang dengan 
sengaja: (a) membuat atau menyebabkan adanya pencatatan palsu dalam pembukuan atau dalam proses laporan, maupun dalam dokumen atau laporan kegiatan usaha, laporan transasksi atau rekening suatu bank". ECW Neloe dikenakan tindak pidana korupsi atas perbuatannya yang telah merugikan keuangan negara. Namun menurut penulis, tindakan penegak hukum yang mengenakan tindak pidana korupsi tidak tepat, karena ada undangundang yang lebih khusus yaitu Undang-Undang Perbankan, sehingga ECW Neloe lebih tepat jika dikenakan sanksi sesuai dengan Undang-Undang Perbankan. Menurut UndangUndang Perbankan perbuatan yang dilakukan oleh ECW Neloe diancam dengan pidana penjara sekurang-kurangnya 5 (lima) tahun dan paling lama 15 (lima belas) tahun serta denda sekurang-kurangnya 10 milyar dan paling banyak 200 milyar.

Berdasarkan analisis diatas, maka jelas tindakan yang dilakukan oleh ECW Neloe merupakan perbuatan ultra vires. Dalam menjalankan tugasnya sebagai perwakilan perseroan, ECW Neloe telah melanggar ketentuan perundangan-undangan serta telah melampaui batas kewenangan seperti yang tercantum dalam anggaran dasar perseroan. Dengan begitu, tindakan ECW Neloe tersebut tidak bisa dilindungi oleh doktrin Business Judgement Rule karena telah melanggar fiduciary duty.

Pada kedua kasus tersebut di atas, unsur yang harus dipenuhi yaitu direksi dalam mengambil suatu keputusan harus didasarkan pada itikad baik, untuk kepentingan terbaik bagi korporasi, tidak ada benturan kepentingan (conflict of interest) serta kehati-hatian (prudent). Apabila direksi telah menerapkan hal-hal tersebut, maka doktrin Business Judgement Rule dapat berfungsi sebagai perlindungan bagi direksi jika dikemudian hari korporasi mengalami kerugian.

Secara keseluruhan, Business Judgement Rule melindungi para direktur yang membuat keputusan yang akhirnya terbukti mengancam perusahaan mereka, sepanjang conditions precedent dipenuhi. Jika tidak, standar hukum yang ketat untuk melakukan penelitian akan diterapkan, karena Business Judgement Rule bukan merupakan magic yang membuat direktur dapat mengenyampingkan, membenarkan atau membuat gugatan lenyap. Karena itu, apabila ada tindakan dari direksi yang kekurang hati-hatian dalam pengelolaan perseroan dapat menimbulkan kerugian pada perseroan terbatas, kerugian tersebut terlihat dari gagalnya mempertahankan sifat kehati-hatian (reasonable care) dalam menjalankan perseroan. Dalam hal demikian, direktur yang bersangkutan harus menanggung atau bertanggung jawab atas kerugian perseroan terbatas. ${ }^{22}$

${ }^{22}$ Binoto Nadapdap, op.cit, hlm.100. 


\section{Tanggung Jawab Direksi dalam Pengelolaan BUMN}

Pada kasus Direktur Utama PT Merpati Nusantara Airlines, Hotasi Nababan dan Direktur Utama PT Bank Mandiri ECW Neloe, keduanya dikenakan tindak pidana korupsi. Penulis tidak sependapat dengan hukuman yang diterima oleh kedua direksi tersebut. Ini dikarenakan yang dirugikan oleh kedua direksi tersebut bukanlah keuangan negara melainkan yang dirugikan adalah perseroan. Karena harta kekayaan perseroan lepas dari harta pendirinya. Dengan begitu tidak tepat jika kerugian perseroan merupakan kerugian negara juga. Permasalahan ini dikarenakan tidak ada harmonisasi antara undang-undang yang satu dengan undang-undang yang lain. definisi mengenai keuangan negara yang diatur di dalam UU BUMN berbeda dengan definisi keuangan negara yang ada di dalam UU Keuangan Negara dan UU Tindak Pidana Korupsi.

Pada dasarnya, business judgement rule dimaksudkan untuk melindungi direksi dan karyawan, yang beritikad baik, dari pertanggungjawaban secara pribadi akibat keputusan bisnis yang menyebabkan kerugian bagi perusahaan. Sebagian kalangan berpendapat konsep business judgement rule telah diadopsi dalam Undang-undang Nomor 40 Tahun 2007 tentang Perseroan Terbatas. Pasal 97 ayat (5) undang-undang ini menyebutkan bahwa anggota direksi tidak dapat dipertangungjawabkan secara pribadi atas kerugian perseroan sebagaimana dimaksud pada ayat (3) jika dapat membuktikan bahwa kerugian tersebut bukan karena kesalahan atau kelalaiannya, telah melakukan pengurusan dengan itikad baik dan kehatihatian untuk kepentingan dan sesuai dengan maksud dan tujuan perseroan, tidak mempunyai benturan kepentingan baik langsung maupun tidak langsung atas tindakan pengurusan yang mengakibatkan kerugian, dan telah mengambil tindakan untuk mencegah timbul atau berlanjutnya kerugian tersebut. ${ }^{23}$ Dengan demikian, tindakan yang dilakukan beberapa direksi perseroan yang menjalankan perusahaan, termasuk melakukan investasi yang dianggap merugikan negara dan kemudian dituduh melakukan tindak pidana korupsi patut dipertanyakan kebenaran atau ketepatannya. Apalagi, jika hal yang dituduhkan kepada direksi itu adalah kerugian yang terjadi suatu transaksi bisnis akibat kesalahan direksi dapat dimintakan tanggung jawab kepada dirinya. ${ }^{24}$

${ }^{23}$ Ibid, hlm. 126.

${ }^{24}$ Ridwan Khairandy, Perseroan..., op.cit, hlm. 235. 
Seharusnya tanggung jawab direksi dalam pengelolaan BUMN berdasarkan Pasal 97 ayat (3) dan (4 UUPT), serta Pasal 1365 KUHPerdata. Pasal 97 ayat (3) UUPT menyatakan bahwa setiap anggota direksi bertanggung jawab secara penuh secara pribadi atas kerugian perseroan apabila yang bersangkutan bersalah atau lalai menjalankan tugas dalam mengurus perseroan. Kemudian Pasal 97 ayat (4) UUPT menyatakan bahwa jika direksi terdiri atas 2 (dua) anggota direksi atau lebih, tanggung jawab secara pribadi tersebut berlaku secara tanggung renteng bagi setiap anggota direksi. Serta Pasal 1365 KUHPerdata menyatakan bahwa setiap perbuatan melawan hukum yang menimbulkan kerugian terhadap orang lain, mewajibkan kepada orang itu karena kesalahannya untuk mengganti kerugian tersebut.

Dengan demikian, tanggung jawab direksi dalam pengelolaan BUMN lebih condong kepada pertanggungjawaban perdata karena dalam hal ini termasuk bagian dari hukum privat dan bukan ranah hukum publik. Direksi bisa dituntut ke ranah pidana apabila direksi tersebut melakukan perbuatan penipuan (fraud) atau penggelapan.

\section{Kesimpulan dan Saran}

\section{Kesimpulan}

a) Sepanjang direksi melakukan tugasnya sesuai peraturan perundang-undangan yang berlaku dan anggaran dasar, serta dalam mengambil suatu keputusan bisnis sudah menerapkan prinsip kehati-hatian maka jika perseroan mengalami kerugian, direksi akan mendapatkan perlindungan dari doktrin Business Judgement Rule. Namun jika direksi tidak menerapkan prinsip kehati-hatian dan juga bertindak ultra vires maka doktrin Business Judgement rule tidak bisa menjadi pelindung bagi direksi.

b) Dalam hal direksi BUMN melakukan tindakan ultra vires, maka direksi tersebut dapat dikenakan Pasal 97 ayat (3) UUPT, pasal ini menentukan bahwa setiap anggota direksi bertanggung jawab penuh sampai pada harta pribadi apabila direksi tersebut melakukan kesalahan atau kelalaian yang mengakibatkan perseroan mengalami kerugian. Kemudian direksi BUMN juga dapat dikenakan Pasal 1365 mengenai perbuatan melawan hukum yang mengakibatkan kerugian ada orang lain, maka harus membayar ganti rugi kepada pihak yang dirugikan. Dengan demikian, Direktur Utama PT Bank Mandiri Tbk (Persero) dan Direktur Utama PT Jamsostek (Persero) seharusnya diajukan gugatan Perbuatan Melawan Hukum dan Pasal 97 ayat (3). 


\section{Saran}

a) Direksi merupakan organ yang perannya paling vital dalam perseroan, karena maju mundurnya perseroan ada pada direksi. Direksi harus berani mengambil resiko bisnis dalam rangka meningkatkan keuntungan bisnis selama dia dalam menjalankan tugasnya berdasarkan peraturan perundang-undangan dan anggaran dasar. Jika direksi ingin melakukan transaksi bisnis, maka sebaiknya dia berkonsultasi terlebih dahulu kepada komisaris sebelum mengambil keputusan. Jika direksi ingin melakukan transasksi bisnis yang tidak tercantum dalam anggaran dasar, maka direksi dapat mengusulkan agar diadakan RUPS.

b) Direksi yang diduga melakukan tindakan ultra vires sebaiknya diajukan gugatan untuk meminta tanggung jawab pribadinya karena, tindakan atau perbuatan yang dilakukan direksi tersebut dapat dikategorikan dalam lingkungan hukum privat dan bukan merupakan wilayah hukum publik seperti yang dilakukan para penegak hukum yang menerapkan tindak pidana korupsi terhadap para direksi tersebut. Dalam hal mengurus perseroan, maka harus berdasarkan Undang-Undang BUMN dan Undang-Undang Perseroan Terbatas. Di dalam Undang-Undang BUMN menyatakan bahwa kekayaan BUMN merupakan kekayaan negara yang dipisahkan, artinya dalam konsep hukum Perseroan Terbatas maka, modal yang disetor oleh pemegang saham ke dalam perseroan telah menjadi kekayaan perseroan.

\section{E. Daftar Pustaka}

Binoto Nadapdap, Hukum Perseroan Terbatas, Cet.1 (Jakarta: Permata Aksara, 2013).

Chatamarrasjid Ais, Penerobosan Cadar Perseroan dan Soal-Soal Aktual Hukum Perusahaan, Cet.1 (Bandung: Citra Aditya Bakti, 2004.

I.G. Rai Wijaya, Hukum Perseroan Terbatas, (Jakarta: Kesain Blanc, 2002).

M. Yahya Harahap, Hukum Perseroan Terbatas, Cet.1, (Jakarta: Sinar Grafika, 2011).

Prasetio, Dilema BUMN, Benturan Penerapan Business Judgement Rule (BJR) dalam keputusan Bisnis Direksi BUMN, Cet.1 (Jakarta: Rayyana komunikasindo: 2014). 
Ridwan Khairandy, Perseroan Terbatas, Doktrin, Peraturan Perundang-undangan, dan Yurisprudensi, Cet.2 (Yogyakarta: Kreasi Total Media, 2009). , Pokok-Pokok Hukum Dagang Indonesia, Cet.1, (Yogyakarta: FH UII Press, 2014).

Rudhi Prasetya, Perseroan Terbatas, Teori dan Praktik, Cet.1 (Jakarta: Sinar Grafika, 2011).

Try Widiyono, Direksi Perseroan Terbatas, Keberadaan, Tugas, Wewenang, dan Tanggung Jawab, (Jakarta: Ghalia Indonesia, 2004).

\section{Data Elektronik}

http://fh.unsoed.ac.id/sites/default/files/VOL8J2008\%20TRUSTO\%20SUBEKTI.pdf 30 Mei 201411.00

http://www.hukumonline.com/berita/baca/lt4feb2faa63db8/kasus-korupsi-merpatisegera-disidang http://repository.usu.ac.id/bitstream/123456789/37040/4/Chapter\%20II.pdf Agustus2014 20.00.

Nindyo Pramono, “Beauty Contest sebagai Business Judgement Rule versus Persaingan Usaha Tidak Sehat", http://www.hukumonline.com 10 September 2014 20.00 WIB.

\section{Peraturan Perundang-undangan}

Undang-Undang Nomor 40 Tahun 2007 tentang Perseroan Terbatas.

Undang-undang Nomor 19 Tahun 2003 tentang BUMN.

Undang-Undang Nomor 17 Tahun 2003 Tentang Keuangan Negara

Peraturan Pemerintah Nomor 45 Tahun 2005 tentang Pendirian, Pengurusan, Pengawasan, dan Pembubaran Badan Usaha Milik Negara.

KUHPerdata

Putusan Mahkamah Agung Nomor 1144/K/Pid/2006 